\title{
The Methodists and Revolutionary America,
} 1760-1800. The Shaping of an Evangelical Culture (cf. Arch. supra. Sébastien Fath)

Princeton, Princeton University Press, 2000, 368 p. (annexes) (cf. supra, pp. 17-40)

\section{(2) OpenEdition}

\section{Journals}

Édition électronique

URL : http://journals.openedition.org/assr/2602

DOI : 10.4000/assr.2602

ISSN : $1777-5825$

Éditeur

Éditions de l'EHESS

Édition imprimée

Date de publication : 1 avril 2004

ISBN : 2-222-96746-5

ISSN : 0335-5985

Référence électronique

" The Methodists and Revolutionary America, 1760-1800. The Shaping of an Evangelical Culture (cf. Arch. supra. Sébastien Fath) », Archives de sciences sociales des religions [En ligne], 126 I avril - juin 2004, document 126.35, mis en ligne le 18 novembre 2005, consulté le 02 mai 2019. URL : http:// journals.openedition.org/assr/2602 ; DOI : 10.4000/assr.2602

Ce document a été généré automatiquement le 2 mai 2019.

Archives de sciences sociales des religions 
The Methodists and Revolutionary America, 1760-1800. The Shaping of an Evangelical Culture (cf. Arch. supra. Sébastien Fath)

Princeton, Princeton University Press, 2000, 368 p. (annexes) (cf. supra, pp. 17-40) 